\title{
Prevalence of chronic obstructive respiratory diseases amongst fishermen
}

\author{
Omar Laraqui ${ }^{1}$, Reda Hammouda ${ }^{2}$, Salwa Laraqui ${ }^{3}$, Nadia Manar ${ }^{3}$, Tarik Ghailan ${ }^{4}$, \\ Jaouda Ben Amor ${ }^{2}$, Frédéric Deschamps ${ }^{1}$, Chakib El Houssine Laraqui ${ }^{3}$ \\ ${ }^{1}$ Department of Occupational Health Medicine Faculty, Reims, France \\ ${ }^{2}$ Moulay Youssef Hospital, Faculty of Medicine and Pharmacy of Rabat, Morocco \\ ${ }^{3}$ Graduate School of Health Engineering, Casablanca, Morocco \\ ${ }^{4}$ Moroccan Society of Maritime Health, Tangier, Morocco
}

\begin{abstract}
Background: The objective was to screen and evaluate the prevalence of respiratory diseases and obstructive ventilatory defects among fishermen in Morocco.

Materials and methods: This observational and cross-sectional epidemiological study involved 924 men over 20 years old and with at least two years of seniority. It included a questionnaire and a spirometry. The questionnaire is composed of four sections: sociodemographic and occupational characteristics, toxic habits, medical history and respiratory clinical symptoms.

Results: The prevalence of symptoms of tracheobronchial irritation was $9.2 \%$ for cough, $8.2 \%$ for sputum $7.8 \%$ for dyspnoea and chest wheezing $8.1 \%$. The frequency of rhinitis was $17.1 \%$, asthma $6.8 \%$, chronic bronchitis 5.6\% and chronic obstructive pulmonary disease (COPD) 4.1\% (5.4\% for current and former smokers versus $1.1 \%$ for non-smokers). The prevalence was reaching $6.8 \%$ among those who smoked more than 10 pack-years and $17.9 \%$ among those who smoked more than 20 pack-years. Among subjects over 40 years old who had smoked more than 10 pack-years, the prevalence of COPD was $8.1 \%$. The comorbidities were frequent.

Conclusions: Smoking was very common among fishermen. Symptoms and respiratory diseases remain underdiagnosed and undertreated. Prevention and early detection must be a priority in this sector.
\end{abstract}

(Int Marit Health 2018; 69, 1: 13-21)

Key words: fishermen, chronic pulmonary diseases, Morocco

\section{INTRODUCTION}

In industrialised countries, obstructive pulmonary diseases (bronchial asthma and chronic obstructive pulmonary disease [COPD]) are a serious public health problem because of their frequency, severity and socio-economic impacts. Their actual prevalence is often underestimated, because unfortunately the first symptoms of the disease are regularly unidentified [1, 2]. In France, among adults, the prevalence of asthma is estimated between $6 \%$ and $7 \%$ [3] and that of COPD between $7.5 \%$ and $10 \%$ [4]. In developing countries, there are few studies assessing the burden of COPD [5-7].
The increase in the prevalence of these diseases around the world is largely related to the increase in pollution and tobacco consumption which are the main risk factors and which are constantly increasing in low-income countries [8-10]. Although the main cause is active smoking, several studies have focused on the close relationship between these diseases and other risk factors that act from childhood to adulthood, such as genetic factors, passive smoking, childhood pulmonary infections, professional and household exposure $[11,12]$. In Morocco, according to the 2014 report of the National Observatory on Drugs and Addictions, the number of smokers was around $34.5 \%$ of

Dr. Chakib El Houssine Laraqui, Graduate School of Health Engineering, 24 rue Lafontaine, Quartier Racine, 20100 Casablanca, Morocco, e-mail: chlaraqui51@gmail.com 
the male population aged 20 and over [13]. According to the World Health Organisation (WHO), in 2020, if no preventive action is taken, the number of victims of tobacco in developing countries could reach $70 \%$ of the total number of victims around the world and COPD will be the third cause of deaths [14]. Given the frequency and severity of these conditions in the general population, we found it useful to screen fishermen particularly exposed to the severe weather and the danger of the Strait of Gibraltar and known for their heavy consumption of tobacco, cannabis and alcohol [15-17]. The objective of this study was to estimate the prevalence of respiratory symptoms and diseases and obstructive ventilatory defects (OVD) among seafarers in Morocco.

\section{MATERIALS AND METHODS}

\section{SUBJECTS}

This observational and cross-sectional epidemiological study took place in two ports of northern Morocco (Tangier and Larache) in 2017 and concerned a representative sample of 924 males, traditional fishermen above 20 years old with 2 years of length of employment. They were randomly selected from exhaustive administrative list of 3052 fishermen. The participation rate was $30.2 \%$.

\section{QUESTIONNAIRE}

We used an individual questionnaire [18-22], inspired by those of the European Coal and Steel Community (ECSC), British Medical Research Council (BMRC) and the American Thoracic Society (ATS) and WHO. It included four sections:

- socio-demographic and professional characteristics: age, body mass index (BMI), occupational history (socio-professional category, length of employment);

- toxic habits: tobacco, cannabis, alcohol;

- medical history (concomitant chronic diseases, comorbidities);

- clinical respiratory symptoms: chronic cough, breathing difficulty (dyspnoea) defined according to Sadoul's classification [23], chronic sputum production, chest wheezing, asthma, rhinitis, chronic bronchitis and COPD.

Asthma is defined as a chronic inflammatory disease of the bronchi characterised by recurrent episodes of coughing, wheezing, chest building and/or dyspnoea usually reversible spontaneously or after treatment. Suggestive symptoms of asthma included chest wheezing, shortness of breath, chest tightness or spasmodic cough caused by stimuli such as cold air, exercise, strong odours, smoke and dust. These symptoms may be associated or isolated. The diagnosis of asthma was confirmed by the questionnaire, the clinical examination and the reversibility of an eventual OVD.
Chronic obstructive pulmonary disease is a common, preventable and treatable disease that is characterised by persistent respiratory symptoms and airflow limitation that is due to airway and/or alveolar abnormalities usually caused by significant exposure to noxious particles or gases. The chronic airflow limitation that is characteristic of COPD is caused by a mixture of small airways disease (e.g. obstructive bronchiolitis) and parenchymal destruction (emphysema); the relative contributions of which vary from person to person. The criteria for its diagnosis and severity are those developed by the GOLD initiative [23]. The diagnosis is made in the presence of an OVD based on a ratio $\mathrm{FEV}_{1} / \mathrm{FVC}<70 \%$ after administration of a bronchodilator. $\mathrm{FEV}_{1}$ is the forced expiratory volume at the first second and the FVC is the forced vital capacity.

Chronic bronchitis is defined as chronic cough and chronic sputum production occurring for at least 3 months (consecutive or not) per year and for at least 2 consecutive years without any other identified cause.

For smoking intoxication, we have individualised current smokers (CS), former smokers (FS) and non-smokers (NS). Subjects were classified as CS if they smoked at the time of the survey or if they stopped less than three months before the study and had smoked more than 100 cigarettes throughout their lives. FS are those who stopped more than 3 months before the study and have smoked more than 100 cigarettes throughout their lives. NS are those who have never smoked or smoked less than 100 cigarettes throughout their lives [24]. Tobacco consumption is quantified in packyears (number of packets smoked per day $\times$ number of years).

The body mass index (BMI) is calculated by dividing the weight in kilograms by the square of the height in meters $\left(\mathrm{kg} / \mathrm{m}^{2}\right)$. The WHO has proposed the following classification: underweight (BMI < 18.5), normal weight (BMI 18.5-24.9), overweight (BMI 25-29.9), obesity (BMI $\geq 30$ ).

\section{SPIROMETRY}

It was carried out using a spirometer (type Winspiro) with disposable turbine provided already calibrated, usable at the output of its Pro packaging. For each person, a spirometry test with three successive trials was conducted. The best of the three was selected considering the degree of cooperation of the subject and the aspect of the flow/ /volume curve. Parameters measured were FVC, $\mathrm{FEV}_{1}$, ratio $\left(\mathrm{FEV}_{1} / \mathrm{FVC}\right.$ ), forced expiratory flow (FEF) from $25 \%$ to $75 \%$ of vital capacity (FEF25-75).

Small airways defect is defined by a $\mathrm{FEV}_{1} / \mathrm{FVC}$ ratio $>70 \%$ and FEF $25-75<80 \%$ of the predicted value.

$\mathrm{FEV}_{1} / \mathrm{FVC}$ ratio less than $70 \%$ define OVD. In this case, a reversibility test was performed 15 min after inhalation (via an inhalation chamber) of $400 \mu \mathrm{g}$ of salbutamol. The test was considered positive at two conditions: FEV $_{1}$ 
Table 1. Sociodemographic and professional characteristics according to smoking status

\begin{tabular}{|c|c|c|c|c|c|}
\hline Characteristics & $\begin{array}{l}\text { Total population } \\
(n=924)\end{array}$ & $\begin{array}{l}\text { CS } \\
431(46.6 \%)\end{array}$ & $\begin{array}{l}\text { FS } \\
215(23.3 \%)\end{array}$ & $\begin{array}{l}\text { CS+FS } \\
646(69.9 \%)\end{array}$ & $\begin{array}{l}\text { NS } \\
278(30.1 \%)\end{array}$ \\
\hline $\begin{array}{l}\text { Age [years]: } \\
20-30 \\
31-40 \\
41-50 \\
>50\end{array}$ & $\begin{array}{l}149(16.1 \%) \\
367(39.7 \%) \\
201(21.8 \%) \\
207(22.4 \%)\end{array}$ & $\begin{array}{l}65(43.6 \%) \\
205(55.9 \%) \\
79(39.3 \%) \\
83(40.1 \%)\end{array}$ & $\begin{array}{l}15(10.1 \%) \\
71(19.3 \%) \\
53(26.4 \%) \\
75(36.2 \%)\end{array}$ & $\begin{array}{l}80(53.7 \%) \\
276(75.2 \%) \\
132(65.7 \%) \\
158(76.3 \%)\end{array}$ & $\begin{array}{l}69(46.3 \%) \\
91(24.8 \%) \\
69(34.3 \%) \\
49(23.7 \%)\end{array}$ \\
\hline $\begin{array}{l}\text { Quantification of cigarette } \\
\text { smoking [pack-years]: } \\
\quad \leq 10 \\
11-20 \\
21-30 \\
31-40 \\
>40\end{array}$ & $\begin{array}{l}- \\
- \\
- \\
-\end{array}$ & $\begin{array}{l}109(25.3 \%) \\
223(51.7 \%) \\
61(14.2 \%) \\
21(4.9 \%) \\
17(3.9 \%)\end{array}$ & $\begin{array}{l}48(22.3 \%) \\
110(51.2 \%) \\
37(17.2 \%) \\
8(3.7 \%) \\
12(5.6 \%)\end{array}$ & $\begin{array}{l}157(24.3 \%) \\
333(51.5 \%) \\
98(15.2 \%) \\
29(4.5 \%) \\
29(4.5 \%)\end{array}$ & $\begin{array}{l}- \\
- \\
- \\
-\end{array}$ \\
\hline $\begin{array}{l}\text { BMI }\left[\mathrm{kg} / \mathrm{m}^{2}\right]: \\
\text { Underweight } \\
\text { Normal } \\
\text { Overweight } \\
\text { Obesity }\end{array}$ & $\begin{array}{l}58(6.3 \%) \\
471(51 \%) \\
279(30.2 \%) \\
116(12.6 \%)\end{array}$ & $\begin{array}{l}37(8.6 \%) \\
220(51 \%) \\
139(32.3 \%) \\
35(8.1 \%)\end{array}$ & $\begin{array}{l}6(2.8 \%) \\
77(35.8 \%) \\
84(39.1 \%) \\
48(22.3 \%)\end{array}$ & $\begin{array}{l}43(6.7 \%) \\
297(46 \%) \\
223(34.5 \%) \\
83(12.8 \%)\end{array}$ & $\begin{array}{l}15(5.4 \%) \\
174(62.6 \%) \\
56(20.1 \%) \\
33(11.9 \%)\end{array}$ \\
\hline $\begin{array}{l}\text { Length of employment [years]: } \\
\quad<10 \\
11-20 \\
>20\end{array}$ & $\begin{array}{l}195(21.1 \%) \\
372(40.3 \%) \\
357(38.6 \%)\end{array}$ & $\begin{array}{l}78(40 \%) \\
199(53.5 \%) \\
154(43.1 \%)\end{array}$ & $\begin{array}{l}18(9.2 \%) \\
68(18.3 \%) \\
129(36.1 \%)\end{array}$ & $\begin{array}{l}96(14.9 \%) \\
267(41.3 \%) \\
283(43.8 \%)\end{array}$ & $\begin{array}{l}99(50.8 \%) \\
105(28.2 \%) \\
74(20.7 \%)\end{array}$ \\
\hline $\begin{array}{l}\text { Other toxic habits: } \\
\text { Cannabis } \\
\text { Alcohol }\end{array}$ & $\begin{array}{l}276(29.9 \%) \\
354(38.3 \%)\end{array}$ & $\begin{array}{l}161(37.4 \%) \\
183(42.5 \%)\end{array}$ & $\begin{array}{l}98(45.6 \%) \\
116(54 \%)\end{array}$ & $\begin{array}{l}259(40.1 \%) \\
299(46.3 \%)\end{array}$ & $\begin{array}{l}17(6.1 \%) \\
55(19.8 \%)\end{array}$ \\
\hline
\end{tabular}

$\mathrm{BMI}$ - body mass index; CS - current smoker; FS - former smoker; NS - no smoker

$>200 \mathrm{~mL}$ compared to the pretest value and ratio $\left(\mathrm{FEV}_{1}\right.$ posttest $-\mathrm{FEV}_{1}$ pretest $) / \mathrm{FEV}_{1}$ predicted $\geq 12 \%$.

Classification of airflow limitation severity is based on post bronchodilator $\mathrm{FEV}_{1}$ value and includes four stages: mild OVD ( $\mathrm{FEV}_{1} \geq 80 \%$ predicted value), moderate OVD $\left(50 \% \leq \mathrm{FEV}_{1}<80 \%\right.$ predicted value), severe OVD $\left(30 \% \leq \mathrm{FEV}_{1}<50 \%\right.$ predicted value) and very severe OVD $\left(\mathrm{FEV}_{1}<30 \%\right.$ predicted value).

\section{PROCEDURE OF THE STUDY}

We previously contacted the delegate of the Ministry of Marine Fisheries, the presidents of the associations of fishermen and the occupational physicians to explain the purpose of the study and obtain their support. The interviews, clinical examinations and spirometries took place at seafarers' health antennas. The singular discussion with each fisherman was carried out in the respect of the confidentiality after his information on the interest of our study. The interview lasted about $30 \mathrm{~min}$ for each person. The questions were formulated orally, if necessary translated into dialectal Arabic, and explained in simple terms and accessible to all. The fishermen answered the questionnaire without difficulty and with enthusiasm.

\section{STATISTICAL ANALYSIS}

The statistical analysis was performed using the SPSS version 11.5 software package. The differences between groups were compared using t tests for continuous variables and $\chi^{2}$ tests for categorical ones. The statistical level of significance was established at $5 \%$. For a proportion, we calculate the lower and upper limits of the 95\% confidence intervals.

\section{RESULTS}

\section{SOCIODEMOGRAPHIC AND PROFESSIONAL CHARACTERISTICS ACCORDING TO SMOKING STATUS}

The average age of our sample was $40.8 \pm 10.9$ years (range 20-71 years), of whom $43.2 \%$ were over 40 years old. The average BMI was $25.1 \pm 3.7 \mathrm{~kg} / \mathrm{m}^{2}$. The prevalence of tobacco smoking (CS+FS) was $69.9 \%$, cannabis smoking was $29.9 \%$ and alcohol consumption was $38.3 \%$. The average of length of employment was $16 \pm 6.7$ years. Almost three quarters (74.7\%) of CS+FS had consumed more than 10 pack-years. The average consumption of tobacco for CS+FS was $16.8 \pm 5.9$ pack-years. The average age of onset of smoking tobacco was $14.5 \pm 2.1$ years. The averages of age of CS+FS versus NS were $41.1 \pm 11.1$ years old versus $38.5 \pm 10.8$ years old $(p<0.7898)$. The averages of BMI were $25.1 \pm 3.4 \mathrm{~kg} / \mathrm{m}^{2}$ versus $25.6 \pm 3.9 \mathrm{~kg} / \mathrm{m}^{2}$ $(p<0.2552)$.

Average of length of employment was $16.7 \pm 6.9$ years versus $14.1 \pm 7.2$ years $(p<0.5015)$. The prevalence of cannabis smoking and alcohol consumption were respectively $40.1 \%$ versus $6.1 \%(p<0.001)$ and $46.1 \%$ versus $19.1 \%(p<0.001)$ (Table 1). 
Table 2. Prevalence of respiratory symptoms and pathologies according to smoking status

\begin{tabular}{|c|c|c|c|c|c|c|}
\hline & $\begin{array}{l}\text { Total population } \\
N=924\end{array}$ & $\begin{array}{l}\text { CS } \\
431(46.6 \%)\end{array}$ & $\begin{array}{l}\text { FS } \\
215(23.3 \%)\end{array}$ & $\begin{array}{l}\text { CS+FS } \\
646(69.9 \%)\end{array}$ & $\begin{array}{l}\text { NS } \\
278(30.1 \%)\end{array}$ & $\mathbf{P}$ \\
\hline \multicolumn{7}{|c|}{$\begin{array}{l}\text { Symptoms of trache- } \\
\text { obronchial irritation: }\end{array}$} \\
\hline Chronic cough & $85(9.2 \%)$ & $51(11.8 \%)$ & $18(8.4 \%)$ & 69 (10.7\%) & $16(5.9 \%)$ & 0.024 \\
\hline Chronic sputum & 76 (8.2\%) & 44 (10.2\%) & $15(7 \%)$ & 59 (9.1\%) & 17 (6.1\%) & 0.161 \\
\hline Dyspnoea & $72(7.8 \%)$ & $38(8.8 \%)$ & $19(8.8 \%)$ & $57(8.8 \%)$ & $15(5.4 \%)$ & 0.099 \\
\hline Chest wheezing & 81 (8.1\%) & $43(10 \%)$ & 19 (8.8\%) & $62(9.6 \%)$ & 19 (6.8\%) & 0.217 \\
\hline Rhinitis & $158(17.1 \%)$ & $83(19.3 \%)$ & 41 (19.1\%) & $124(19.2 \%)$ & 34 (12.2\%) & 0.013 \\
\hline Asthma & $62(6.8 \%)$ & $29(6.7 \%)$ & $16(7.4 \%)$ & $45(7 \%)$ & 17 (6.1\%) & 0.741 \\
\hline Chronic bronchitis & 52 (5.6\%) & $31(7.2 \%)$ & 17 (7.9\%) & $48(7.4 \%)$ & $4(1.4 \%)$ & 0.0001 \\
\hline COPD & $38(4.1 \%)$ & $24(5.6 \%)$ & $11(5.1 \%)$ & 35 (5.4\%) & $3(1.1 \%)$ & 0.004 \\
\hline
\end{tabular}

COPD - chronic obstructive pulmonary disease; CS - current smoker; FS - former smoker; NS - no smoker

Table 3. Prevalence of respiratory function abnormalities according to the degree of severity and smoking status

\begin{tabular}{llllllc}
\hline $\begin{array}{l}\text { Spirometric } \\
\text { abnormalities }\end{array}$ & Total & CS & FS & CS+FS & NS & P \\
\hline Small airways syndrome & $\mathbf{8 1 / 9 2 4}(\mathbf{8 . 8} \%)$ & $\mathbf{4 2 / 4 3 1}(\mathbf{9 . 7} \%)$ & $\mathbf{2 4 / 2 1 5}(\mathbf{1 1 . 2} \%)$ & $\mathbf{6 6 / 6 4 6}(\mathbf{1 0 . 2} \%)$ & $\mathbf{1 5 / 2 7 8 ( 5 . 4 \% )}$ & \\
Mild OVD & $18(1.9 \%)$ & $16(3.7 \%)$ & $9(4.2 \%)$ & $25(3.9 \%)$ & $6(2.2 \%)$ & 0.260 \\
Moderate OVD & $29(3.1 \%)$ & $16(3.7 \%)$ & $9(4.2 \%)$ & $25(3.9 \%)$ & $4(1.4 \%)$ & 0.082 \\
Severe OVD & $2(0.2 \%)$ & $0(0 \%)$ & $2(0.9 \%)$ & $2(0.3 \%)$ & $0(0 \%)$ & 0.875 \\
Very severe OVD & $1(0.1 \%)$ & $1(0.2 \%)$ & $0(0 \%)$ & $1(0.2 \%)$ & $0(0 \%)$ & 0.664
\end{tabular}

CS - current smoker; FS - former smoker; NS - no smoker; OVD - obstructive ventilatory defect

\section{PREVALENCE OF RESPIRATORY SYMPTOMS AND PATHOLOGIES ACCORDING TO SMOKING STATUS}

The respective prevalences of chronic cough, rhinitis, chronic bronchitis and COPD were significantly greater among CS+FS than among NS (Table 2).

\section{PREVALENCE OF RESPIRATORY FUNCTION ABNORMALITIES ACCORDING TO THE DEGREE OF SEVERITY AND SMOKING STATUS}

Among total population, the prevalence of ventilatory defect was $8.8 \%: 3.4 \%$ for the small airway syndrome, $1.9 \%$ for the mild OVD, 3.1\% for the moderate OVD and $0.3 \%$ for the severe to very severe OVD. Prevalences of spirometric abnormalities were significantly higher among CS+FS than among NS $(10.2 \%$ vs. $5.4 \%, p=0.024)$. All stages of ventilatory defect were more frequent among CS+FS than among NS (Table 3).

\section{CLINICAL CHARACTERISTICS OF SUBJECTS WITH COPD ACCORDING TO TOBACCO STATUS}

Among the 38 fishermen with COPD, the average age was $48.4 \pm 7.9$ years (with extremes ranging from 32 to 71 years) and $78.9 \%$ were over 40 years old. The associated respiratory diseases were asthma in $18.4 \%$, rhinitis in
$23.7 \%$ and chronic bronchitis in $89.5 \%$. The most common comorbidities were high blood pressure (22\%), diabetes and metabolic syndrome (16\%), cardiovascular diseases such as heart diseases, phlebitis and arteritis (15\%), psychological disorders such as anxiety, depression and dyssomnia (17\%), digestive disorders (19\%) and musculoskeletal dysfunctions (21\%). Among people with COPD, $42.5 \%$ reported no respiratory symptom that could suggest the diagnosis of COPD. Only the 3 patients with a severe and very severe stage of the COPD consulted a specialist and benefited of spirometry. That explains the high percentage (92.1\%) of undiagnosed COPD. The prevalence of tobacco smoking (CS+FS) was $92.1 \%$, cannabis smoking was $71.4 \%$ and alcohol consumption was $55.3 \%$. Among CS+FS, average of quantification of cigarette smoking was $29.5 \pm 6.9$ pack-years and $94.3 \%$ had smoked more than 10 pack-years. The average age of onset of smoking cigarette was $13 \pm 1.2$ years (Table 4).

\section{CLINICAL CHARACTERISTICS OF SUBJECTS WITH COPD ACCORDING TO TOBACCO STATUS REFERRED TO TOTAL POPULATION}

Among total population, the prevalence of COPD was $4.1 \%$ and reached $5.4 \%$ among $C S+F S$ versus $1.1 \%$ among NS with significate difference $(p=0.004)$. The frequency 
Table 4. Clinical characteristics of subjects with chronic obstructive pulmonary disease according to tobacco status

\begin{tabular}{|c|c|c|c|c|c|}
\hline & $\begin{array}{l}\text { Total } \\
38(100 \%)\end{array}$ & $\begin{array}{l}\text { FS } \\
24(63.2 \%)\end{array}$ & $\begin{array}{l}\text { CS } \\
11(28.9 \%)\end{array}$ & $\begin{array}{l}\text { FS+CS } \\
35 \text { (92.1\%) }\end{array}$ & $\begin{array}{l}\text { NS } \\
3(7.9 \%)\end{array}$ \\
\hline \multicolumn{6}{|l|}{ Age [years]: } \\
\hline $20-30$ & $0(0 \%)$ & $0(0 \%)$ & $0(0 \%)$ & $0(0 \%)$ & $0(0 \%)$ \\
\hline $31-40$ & $8(21 \%)$ & 7 (29.2\%) & $1(9.1 \%)$ & $8(22.9 \%)$ & $0(0 \%)$ \\
\hline $41-50$ & $9(23.7 \%)$ & $5(20.8 \%)$ & $3(27.3 \%)$ & $8(22.9 \%)$ & $1(33,3)$ \\
\hline$>50$ & $21(55.3 \%)$ & $12(50 \%)$ & $7(63.6 \%)$ & $19(54.3 \%)$ & $2(66,7)$ \\
\hline \multicolumn{6}{|l|}{ BMI $\left[\mathrm{kg} / \mathrm{m}^{2}\right]$ : } \\
\hline Underweight & $11(28.9 \%)$ & 9 (37.5\%) & $2(18.2 \%)$ & $11(31.4 \%)$ & $0(0 \%)$ \\
\hline Normal & $16(42.1 \%)$ & $11(45.8 \%)$ & 4 (36.4\%) & 15 (42.9\%) & 1 (33.3\%) \\
\hline Overweight & $8(21.1 \%)$ & $4(16.7 \%)$ & $3(27.3 \%)$ & $7(20 \%)$ & $1(33.3 \%)$ \\
\hline Obesity & $3(7.9 \%)$ & $0(0 \%)$ & $2(18.2 \%)$ & $2(5.7 \%)$ & $1(33.3 \%)$ \\
\hline \multicolumn{6}{|c|}{$\begin{array}{l}\text { Quantification of cigarette } \\
\text { smoking (pack-years): }\end{array}$} \\
\hline$\leq 10$ & - & $1(4.2 \%)$ & $1(9.1 \%)$ & $2(5.7 \%)$ & - \\
\hline $11-20$ & - & 3 (12.5\%) & 2 (18.2\%) & $5(14.3 \%)$ & - \\
\hline $21-30$ & - & $6(25 \%)$ & 2 (18.2\%) & 8 (22.9\%) & - \\
\hline $31-40$ & - & 7 (29.2\%) & $2(18.2 \%)$ & $9(25.7 \%)$ & - \\
\hline$>40$ & - & 7 (29.2\%) & $4(36.4 \%)$ & $11(31.4 \%)$ & - \\
\hline \multicolumn{6}{|l|}{ Severity of COPD: } \\
\hline Mild & $11(28.9 \%)$ & $7(29.2 \%)$ & $2(18.2 \%)$ & $7(20 \%)$ & $2(66.7 \%)$ \\
\hline Moderate & $24(63.2 \%)$ & $16(66.7 \%)$ & 7 (63.6\%) & $25(71.4 \%)$ & $1(33.3 \%)$ \\
\hline Severe & $2(5.3 \%)$ & $0(0 \%)$ & $2(18.2 \%)$ & $2(5.7 \%)$ & $0(0 \%)$ \\
\hline Very severe & $1(2.6 \%)$ & $1(4.2 \%)$ & $0(0 \%)$ & $1(2.8 \%)$ & $0(0 \%)$ \\
\hline \multicolumn{6}{|l|}{$\begin{array}{l}\text { Associated respiratory } \\
\text { diseases: }\end{array}$} \\
\hline Rhinitis & $9(23.7 \%)$ & $3(12.5 \%)$ & $4(36.4 \%)$ & $7(20 \%)$ & $2(66.7 \%)$ \\
\hline Asthma & 7 (18.4\%) & $3(12.5 \%)$ & $2(18.2 \%)$ & $5(14.3 \%)$ & $2(66.7 \%)$ \\
\hline Chronic bronchitis & $34(89.5 \%)$ & $21(87.5 \%)$ & $10(90.9 \%)$ & $31(88.6 \%)$ & $3(100 \%)$ \\
\hline \multicolumn{6}{|l|}{ Other toxic habits: } \\
\hline Cannabis & $26(68.4 \%)$ & $17(70.8 \%)$ & $8(72.7 \%)$ & $25(71.4 \%)$ & $1(33.3 \%)$ \\
\hline Alcohol & $21(55.3 \%)$ & $11(45.8 \%)$ & $10(90.9 \%)$ & $21(60 \%)$ & $0(0 \%)$ \\
\hline
\end{tabular}

$\mathrm{BMI}$ - body mass index; COPD - chronic obstructive pulmonary disease; CS - current smoker; FS - former smoker; NS - no smoker

was $6.7 \%$ among those who smoked more than 10 packyears and $17.9 \%$ among those who smoked more than 20 pack-years. This prevalence was $2.2 \%$ among CS+FS under 40 years old versus $9.3 \%$ among those over 40 years old $(p=0.0001)$. In subjects over 40 years old and had smoked more than 10 pack-years, it was $8.1 \%$. Among NS, it was equal $2.5 \%$ for those over 40 years old (Table 5 ).

\section{CLINICAL FEATURES IN SUBJECTS WITH COPD ACCORDING TO DEGREE OF SEVERITY}

92.1\% of those with COPD are at mild and moderate stages and $77.1 \%$ are over 40 years old. For the severe and very severe stages, all people were over 40 years old and had a polyaddiction to tobacco, cannabis and alcohol (Table 6).

\section{DISCUSSION}

The prevalence of toxic habits is constantly increasing in developing countries and all professional sectors and activities are affected $[13,25]$. Seafarers are a particular target because of the dangerousness and complexity of their work.
This laborious activity, with irregular and atypical work and numerous constraints, requires courage and commitment of fishermen. In these countries, risk-taking behaviour among artisanal fishermen is still an observational epidemiological reality, associated with significant morbidity and mortality. These dangerous behaviours are very diverse and include high prevalence of psychoactive substance use $[15,16]$. Addictive behaviours (particularly smoking tobacco and cannabis) are very common among the fishermen who suffer of health problems and poor access to healthcare utilities. In our study, the prevalence of tobacco smoking was $46.6 \%$, cannabis smoking $29.9 \%$ and alcohol consumption $38.3 \%$. Two other surveys $[15,16]$, the first relating to risk behaviours and the second to the consumption of addictive substances among Moroccan fishermen, showed similarly high rates of tobacco smoking (58.5\% and 52.3\%), cannabis smoking (36.2\% and $31.7 \%$ ) and alcohol consumption (36.5\% and $38.9 \%$ ). These prevalences are significantly higher than the general male population over the age of 20 , which are respectively $34.5 \%, 9 \%$ and $14 \%$ [13]. 
Table 5. Clinical characteristics of subjects with chronic obstructive pulmonary disease according to tobacco status referred to total population

\begin{tabular}{|c|c|c|c|c|c|}
\hline & $\begin{array}{l}\text { Total } \\
38 / 924 \text { (4.1\%) } \\
\end{array}$ & $\begin{array}{l}\text { CS } \\
24 / 431(5.6 \%)\end{array}$ & $\begin{array}{l}\text { FS } \\
11 / 215(5.1 \%)\end{array}$ & $\begin{array}{l}\text { CS+FS } \\
35 / 646(5.4 \%)\end{array}$ & $\begin{array}{l}\text { NS } \\
3 / 278(1.1 \%)\end{array}$ \\
\hline \multicolumn{6}{|l|}{ Age [years]: } \\
\hline $20-30$ & 0 & 0 & 0 & 0 & 0 \\
\hline $31-40$ & $8 / 367$ (2.2\%) & $7 / 205$ (3.4\%) & $1 / 71(1.4 \%)$ & $8 / 276(2.9 \%)$ & 0 \\
\hline $41-50$ & $9 / 201$ (4.5\%) & $5 / 79(6.3 \%)$ & $3 / 53(5.7 \%)$ & $8 / 132$ (6.1\%) & $1 / 69(1.4 \%)$ \\
\hline$>50$ & 21/207 (10.1\%) & $12 / 83(14.5 \%)$ & $7 / 75$ (9.3\%) & $19 / 158(12 \%)$ & $2 / 49$ (4.1\%) \\
\hline \multicolumn{6}{|l|}{ BMI [kg/m²]: } \\
\hline Underweight & $11 / 58(19 \%)$ & 9/37 (24.3\%) & $2 / 6(33.3 \%)$ & $11 / 43(25.6 \%)$ & 0 \\
\hline Normal & 16/471 (3.4\%) & $11 / 220(5 \%)$ & $6 / 77$ (7.8\%) & 15/297 (5.1\%) & 1/174 (0.6\%) \\
\hline Overweight & $8 / 279$ (2.9\%) & $4 / 139(2.9 \%)$ & $3 / 84(3.6 \%)$ & $7 / 223$ (3.1\%) & $1 / 56(1.8 \%)$ \\
\hline Obesity & $3 / 116(2.6 \%)$ & $0 / 35$ & $2 / 48(4.2 \%)$ & $2 / 83(2.4 \%)$ & $1 / 33(3 \%)$ \\
\hline \multicolumn{6}{|c|}{$\begin{array}{l}\text { Importance du smoking } \\
\text { (pack-years): }\end{array}$} \\
\hline$\leq 10$ & - & $1 / 109$ (0.9\%) & $1 / 48(2.1 \%)$ & 2/157 (1.3\%) & - \\
\hline $11-20$ & - & $3 / 223(1.3 \%)$ & $2 / 110(1.8 \%)$ & $5 / 333(1.5 \%)$ & - \\
\hline $21-30$ & - & $6 / 61(9.8 \%)$ & $2 / 37(5.5 \%)$ & $8 / 98(8.2 \%)$ & - \\
\hline $31-40$ & - & 7/21 (33.3\%) & $2 / 8(25 \%)$ & $9 / 29(31 \%)$ & - \\
\hline$>40$ & - & $7 / 17$ (41.1\%) & 4/12 (33.3\%) & $11 / 29(37.9 \%)$ & - \\
\hline \multicolumn{6}{|l|}{ Other toxic habits: } \\
\hline Cannabis & $26 / 276$ (9.4\%) & $17 / 161(10.6 \%)$ & 8/98 (8.2\%) & $25 / 259$ (9.7\%) & $1 / 17(5.9 \%)$ \\
\hline Alcohol & 21/354 (5.9\%) & $11 / 183(6 \%)$ & $10 / 116(8.6 \%)$ & $21 / 299(7 \%)$ & 0 \\
\hline \multicolumn{6}{|l|}{ Severity of COPD: } \\
\hline Light & $11 / 18(61.1 \%)$ & $7 / 9(77.8 \%)$ & $2 / 4(50 \%)$ & $7 / 13(53.8 \%)$ & $2 / 5(40 \%)$ \\
\hline Moderate & $24 / 29(82.8 \%)$ & $16 / 16(100 \%)$ & $7 / 9(77.8 \%)$ & $25 / 25$ (100\%) & $1 / 4(25 \%)$ \\
\hline Severe & $2 / 2(100 \%)$ & 0 & $2 / 2(100 \%)$ & $2 / 2(100 \%)$ & 0 \\
\hline Very severe & $1 / 1(100 \%)$ & $1 / 1(100 \%)$ & 0 & $1 / 1(100 \%)$ & 0 \\
\hline \multicolumn{6}{|l|}{$\begin{array}{l}\text { Respiratory associated } \\
\text { diseases: }\end{array}$} \\
\hline Rhinitis & $9 / 158$ (5.7\%) & $3 / 83$ (3.6\%) & $4 / 41(9.8 \%)$ & $7 / 124(5.6 \%)$ & 2/34 (5.9\%) \\
\hline Asthma & $7 / 62(11.3 \%)$ & $3 / 29$ (10.3\%) & $2 / 16$ (12.5\%) & $5 / 45(11.1 \%)$ & $2 / 17(11.8 \%)$ \\
\hline Chronic bronchitis & $34 / 52(65.4 \%)$ & $21 / 31(67.7 \%)$ & $10 / 17(58.8 \%)$ & $31 / 48(64.6 \%)$ & $3 / 4(75 \%)$ \\
\hline
\end{tabular}

COPD - chronic obstructive pulmonary disease; CS - current smoker; FS - former smoker; BMI - body mass index; NS - no smoker

Table 6. Clinical features in subjects with chronic obstructive pulmonary disease according to degree of severity

\begin{tabular}{|c|c|c|c|c|c|}
\hline $\begin{array}{l}\text { Obstructive ventilatory } \\
\text { defects }\end{array}$ & $\begin{array}{l}\text { Total } \\
38(100 \%)\end{array}$ & $\begin{array}{l}\text { Light } \\
11(28.9 \%)\end{array}$ & $\begin{array}{l}\text { Moderate } \\
24(63.2 \%)\end{array}$ & $\begin{array}{l}\text { Severe } \\
2(5.3 \%)\end{array}$ & $\begin{array}{l}\text { Very severe } \\
1(2.6 \%)\end{array}$ \\
\hline \multicolumn{6}{|l|}{ Age [years]: } \\
\hline $31-40$ & $8(21.1 \%)$ & $2(18.2 \%)$ & $6(25 \%)$ & $0(0 \%)$ & $0(0 \%)$ \\
\hline $41-50$ & $9(23.7 \%)$ & $3(27.3 \%)$ & $5(20.8 \%)$ & $1(50 \%)$ & $0(0 \%)$ \\
\hline$>50$ & $21(55.3 \%)$ & $6(54.5 \%)$ & $13(54.2 \%)$ & $1(50 \%)$ & $1(100 \%)$ \\
\hline \multicolumn{6}{|l|}{ Body mass index $\left[\mathrm{kg} / \mathrm{m}^{2}\right]$ : } \\
\hline Underweight & $11(28.9 \%)$ & $0(0 \%)$ & $2(8.3 \%)$ & $1(50 \%)$ & $0(0 \%)$ \\
\hline Normal & $18(47.4 \%)$ & $6(54.5 \%)$ & $19(79.2 \%)$ & $1(50 \%)$ & $1(100 \%)$ \\
\hline Overweight & $6(15.8 \%)$ & $4(36.4 \%)$ & $1(4.2 \%)$ & $0(0 \%)$ & $0(0 \%)$ \\
\hline Obesity & $3(7.9 \%)$ & $1(9.1 \%)$ & $2(8.3 \%)$ & $0(0 \%)$ & $0(0 \%)$ \\
\hline Smoking tobacco & 35 (92.1\%) & $8(72.7 \%)$ & $24(100 \%)$ & $2(100 \%)$ & $1(100 \%)$ \\
\hline Smoking cannabis & $26(68.4 \%)$ & $6(54.5 \%)$ & $17(70.8 \%)$ & $2(100 \%)$ & $1(100 \%)$ \\
\hline Consuming alcohol & $21(55.3 \%)$ & $5(45.5 \%)$ & $13(54.2 \%)$ & $2(100 \%)$ & $1(100 \%)$ \\
\hline
\end{tabular}

In our study, the prevalence of asthma in the total population was $6.8 \%$ ( $7 \%$ among CS+FS vs. $6.1 \%$ among NS, $p=0.741)$ and $7.3 \%$ for chronic bronchitis $(9.1 \%$ among CS+FS vs. $2.9 \%$ among NS, $p=0.0001)$. In a meta-analysis [26] of 38 studies, the combined prevalence of chronic bronchitis was 6.4\%. Among adults in France, 
the prevalence of asthma was estimated between $6 \%$ and $7 \%[3]$.

The prevalence of COPD in our total population was 4.1\% (5.4\% among CS+FS vs. $1.1 \%$ among NS, $p=0.004)$. It reached $6.7 \%$ among those who smoked more than 10 pack-years and $17.9 \%$ among those who smoked more than 20 pack-years. In a multicentric study of 62,086 subjects in eleven countries, including Morocco, 3.5\% fulfilled the "epidemiological" definition of COPD of whom $47.5 \%$ reported experiencing an exacerbation of their respiratory condition [6, 7]. In France the prevalence of COPD is estimated between $7.5 \%$ and $10 \%$ [4]. The combined COPD prevalence $7.6 \%$, found in a meta-analysis of 37 studies using the GOLD diagnostic criteria [26] is comparable to our result, which is $5.4 \%$. The prevalence of COPD increases with age. In our study, among CS+FS, it is $2.2 \%$ among people under 40 years old against $9.3 \%$ among those over 40 years old. For NS, it is equal to $0 \%$ for those under 40 years old against $2.5 \%$ for those over 40 years old. In the literature, the prevalence of physiologically defined COPD in adults over 40 years old is $9-10 \%$ [26]. In the BOLD study, the prevalence of COPD has doubled for every decade [27]. In our study, it was equal to $2.9 \%$ between 30 and 40 years, $6.1 \%$ between 40 and 50 years and $12 \%$ over 50 years.

In the Algerian study [5], the prevalence of COPD was $4.9 \%$ and reached $16.1 \%$ among men over 40 years of age. It was $25.7 \%$ among smokers versus $2.5 \%$ among NS. In our study, the prevalence of COPD among subjects over 40 years old was $7.4 \%$ and among smokers over 40 years old was $9.3 \%$. These high frequencies in Algiers can be explained by a higher prevalence of smokers up to $62 \%$ and greater quantification of cigarette smoking, which is 15 pack-years among $69.3 \%$ and 30 pack-years among $38.5 \%$. In our study, only $24.2 \%$ smoked more than 10 pack-years and $9 \%$ more than 30 pack-years.

Nonsmokers may also develop COPD, which is the result of a complex interplay long-term cumulative exposure to noxious gases and particles combined with a variety of host factors including genetics, airway hyper-responsiveness and poor lung growth during childhood [28-30]. In many developing countries air pollution resulting from the burning of wood and other biomass fuels and occupational exposure including dust chemical agents and fumes are major COPD risk factors [31, 32]. There is strong evidence that the prevalence of smoking and the risk of developing COPD are inversely related to educational level and socioeconomic status [24, 33]. Among our fishermen with COPD, $7.9 \%$ were NS. This prevalence resulted of occupational risk factors, of which the most important were severe weather, night work, exposure to air pollution (engine gases, passive smoking) and low socioeconomic status. A literature review conducted by the American Thoracic Society reported that the risk fraction attributable to occupational aetiologies was approximately $15 \%$ for chronic bronchitis (11\% to $26 \%$ ) and $19 \%$ for obstructive airway disease [34]. In our study, $11.9 \%$ of chronic bronchitis and 18\% of OVD were found among NS. Recent studies suggest an additive effect of smoking and occupational exposure to the risk of developing COPD in people exposed to gas, dust, fumes and steam [35]. Several nuisances or professional sectors and activities have been associated epidemiologically with an excess risk of COPD, especially mining industry, construction, public works, iron and steel [2], to which we could add fishermen. In our study, the prevalence of severity stages of COPD was $36 \%$ mild, $58 \%$, moderate, $4 \%$ severe and $2 \%$ very severe. This distribution is comparable to that observed in the Algiers study: $65.5 \%, 29.4 \%, 3.3 \%$ and $2.2 \%$ [5]. COPD is underdiagnosed, inadequately assessed and treated while it is a potentially serious chronic progressive respiratory which is a global burden and requires long-term treatment. In a multicentric study [7], only $31.8 \%$ claimed to have received a diagnosis of COPD from a physician and $20.6 \%$ had undergone spirometry in the previous year. In our study, $42.5 \%$ of people with COPD did not report any respiratory symptoms that could suggest the diagnosis. This is due to the trivialisation of functional symptoms including dyspnoea when it exists especially in smokers. Only 3 patients with a severe and very severe stage of the disease had benefited from spirometry (7.9\%) which explains the high percentage (92.1\%) of underdiagnosed COPD. This high frequency of under-diagnosis varies according to studies from $45 \%$ to $97 \%$ [28]. In our study, only half $(50.1 \%)$ of chronic bronchitis had associated COPD (52.5\% for CS+FS and $37.5 \%$ for NS). COPD can progress from chronic bronchitis or appear insidiously without pre-existing chronic bronchitis, making diagnosis often difficult. In our country, the diagnosis of COPD is usually late; it occurs during an exacerbation with significant dyspnoea and/or an episode of infection in large hospitals or specialized medical office in large cities.

\section{LIMITATIONS OF THE STUDY}

Our study has two main limitations. It is cross-sectional; the healthy worker effect constitutes a bias of selection. The weak points of the self-declaration must be underlined especially for the consumption of the psychoactive substances with in the first place the alcohol. The prevalence of alcohol consumption is most likely underestimated because the Muslim confession of our target population prohibits its consumption and the related issues remain taboo.

\section{CONCLUSIONS}

The prevalence of chronic occupational respiratory diseases is a serious public health and occupational health 
problem. The occupational physicians should take the necessary time to reduce this burden by primary prevention (fight against active and passive smoking and occupational pollution) and secondary prevention (early screening, monitoring, and following up of affected patients). The impact of these diseases on the daily activities of the patient is a major element and should be systematically and rigorously evaluated. Several professional activities have been associated with an excess of risk factors of chronic respiratory diseases [2] to which we could add the fishery sector.

\section{REFERENCES}

1. Société Pneumologique de Langue Française. Recommandations de la Société de Pneumologie de Langue Française sur la prise en charge de la BPCO (mise à jour 2009). Rev Mal Resp. 2010; 27(5): 522-548, doi: 10.1016/j.rmr.2010.04.010.

2. Ameille J, Dalphin JC, Descatha A, et al. La broncho-pneumopathie chronique obstructive professionnelle : une maladie méconnue. Revue mal resp. 2006; 23(supl 4): 119-30.

3. Delmas MC, Fuhrman C. L'asthme en France : synthèse des données épidémiologiques descriptives. Rev Mal Resp. 2010; 27(2): 151-159, doi:10.1016/j.rmr.2009.09.001.

4. Fuhrman C, Delmas MC. Épidémiologie descriptive de la bronchopneumopathie chronique obstructive (BPCO) en France. Rev Mal Resp. 2010; 27(2): 160-168, doi: 10.1016/j.rmr.2009.08.003.

5. Khelafi R, Aissanou A, Tarsift S, et al. Épidémiologie de la bronchopneumopathie chronique obstructive dans la wilaya d'Alger. Rev Mal Resp. 2011; 28(1): 32-40, doi: 10.1016/j. rmr.2010.06.026.

6. Idrees M, Koniski ML, Taright S, et al. BREATHE Study Group. Management of chronic obstructive pulmonary disease in the Middle East and North Africa: results of the BREATHE study. Respir Med. 2012; 106 Suppl 2: S33-S44, doi: 10.1016/S09546111(12)70013-6, indexed in Pubmed: 23290703.

7. Uzaslan E, Mahboub B, Beji M, et al. BREATHE Study Group. The burden of chronic obstructive pulmonary disease in the Middle East and North Africa: results of the BREATHE study. Respir Med. 2012; 106 Suppl 2: S45-S59, doi: 10.1016/S09546111(12)70014-8, indexed in Pubmed: 23290704.

8. Burrows B, Knudson RJ, Cline MG, et al. Quantitative relationships between cigarette smoking and ventilatory function. Quantitative relationships between smoking cigarette and ventilatory function Am Rev Respir Dis. 1977; 115(2): 195-205, doi: 10.1164/ arrd.1977.115.2.195, indexed in Pubmed:842934.

9. Stang P, Lydick E, Silberman C, et al. The prevalence of COPD: using smoking rates to estimate disease frequency in the general population. Chest. 2000; 117(5 Suppl 2): 354S-359S, doi: 10.1378/ chest.117.5_suppl_2.354s, indexed in Pubmed: 10843976.

10. Lundback B, Lindberg A, Lindstrom M, et al. Not 15 but 50\% of smokers develop COPD?--Report from the Obstructive Lung Disease in Northern Sweden Studies. Respir Med. 2003; 97(2): 115-122, doi: 10.1053/rmed.2003.1446, indexed in Pubmed: 12587960 .

11. Svanes C, Sunyer J, Plana E, et al. Early life origins of chronic obstructive pulmonary disease. Thorax. 2010; 65(1): 14-20, doi: 10.1136/thx.2008.112136, indexed in Pubmed: 19729360.

12. Raherison C, Girodet PO. Epidemiology of COPD. Eur Respir Rev. 2009; 18(114): 213-221, doi: 10.1183/09059180.00003609, indexed in Pubmed: 20956146.
13. Jalal T, El Omari F, Sabir M. Rapport annuel de l'Observatoire national des drogues et addictions. Maroc, Rapport officiel 2014:108. www.onda-drogues.com (2014).

14. Tessier JF, Nejjari C. Bennani Othmani M. Epidémiologie du tabagisme dans les pays de la méditerranée. Int J Tuberc Lung Dis. 1999; 3(10): 927-937.

15. Laraqui O, Laraqui S, Manar N, et al. Risk-taking behaviours among fishermen in Morocco by the evaluation of. Int Marit Health. 2017; 68(2): 83-89, doi:10.5603/IMH.2017.0016, indexed in Pubmed: 28660610.

16. Laraqui O, Laraqui S, Manar N, et al. Prevalence of consumption of addictive substances amongst Moroccan fishermen. Int Marit Health. 2017; 68(1): 19-25, doi: 10.5603/IMH.2017.0004, indexed in Pubmed: 28357832.

17. Kauffmann F, Annesi-Maesano I, Liard R, et al. Construction et validation d'un questionnaire en épidémiologie respiratoire. Rev Mal Respir. 2002; 19(3): 323-333, indexed in Pubmed: 12166414.

18. Minette A. Questionnaire of the European Community for Coal and Steel (ECSC) on respiratory symptoms. 1987-updating of the 1962 and 1967 questionnaires for studying chronic bronchitis and emphysema. Eur Respir J. 1989; 2(2): 165-177, indexed in Pubmed: 2703044.

19. MRC committee on the aetiology of chronic bronchitis. Standardised questionnaires on respiratory symptoms. Br Med J. 1960; 2: 16-65.

20. American Lung Association Recommended respiratory disease questionnaires for use with adults and children in epidemiological research. Am Rev Respir Dis. 1978; 6: 7-53.

21. Osterman JW, Armstrong BG, Ledoux E, et al. Comparison of French and English versions of the American Thoracic Society respiratory questionnaire in a bilingual working population. Int J Epidemiol. 1991; 20(1): 138-143, doi: 10.1093/ije/20.1.138, indexed in Pubmed: 2066212.

22. Sadoul P. Evaluation du déficit fonctionnel et respiratoire. Bull Eur Physiopath Respir. 1983; 19: 3-6.

23. Pocket guide to COPD diagnosis, management, and prevention. Global Initiative for chronic obstructive lung disease, 2017 report.http://goldcopd.org/pocket-guide-copd-diagnosis-management-prevention-2016/.

24. El Rhazi K, Nejjari C, Berraho M, et al. Inequalities in smoking profiles in Morocco: the role of educational level. Int J Tuberc Lung Dis. 2008; 12(11): 1327-1332, indexed in Pubmed: 18926045.

25. Goullé JP, Morel F. Addictions en milieu professionnel. Académie nationale de médecine, Paris. http://www.academie-medecine. frarticles-du-bulletinpublicationidpublication=100768 (Rapport 10 october 2017).

26. Halbert RJ, Natoli JL, Gano A, et al. Global burden of COPD: systematic review and meta-analysis. Eur Respir J. 2006; 28(3): 523-532, doi:10.1183/09031936.06.00124605, indexed in Pubmed: 16611654.

27. Buist AS, McBurnie MA, Vollmer WM, et al. International variation in the prevalence of COPD (the BOLD Study): a population-based prevalence study. Lancet. 2005; 366: 1875-81.

28. Lange $P$, Celli $B$, Agustí A, et al. Lung-Function Trajectories Leading to Chronic Obstructive Pulmonary Disease. N Engl J Med. 2015; 373(2): 111-122, doi: 10.1056/NEJMoa1411532, indexed in Pubmed: 26154786.

29. Stern DA, Morgan WJ, Wright AL, et al. Poor airway function in early infancy and lung function by age 22 years: a non-selective longitudinal cohort study. Lancet. 2007; 370(9589): 758-764, doi: 10.1016/ S0140-6736(07)61379-8, indexed in Pubmed: 17765525.

30. Tashkin DP, Altose MD, Bleecker ER, et al. The lung health study: airway responsiveness to inhaled methacholine in smokers with mild 
to moderate airflow limitation. The Lung Health Study Research Group. Am Rev Respir Dis. 1992; 145(2 Pt 1): 301-310, doi: 10.1164/ ajrccm/145.2_Pt_1.301, indexed in Pubmed: 1736734.

31. Eisner MD, Anthonisen N, Coultas D, et al. Committee on Nonsmoking COPD, Environmental and Occupational Health Assembly. An official American Thoracic Society public policy statement: Novel risk factors and the global burden of chronic obstructive pulmonary disease. Am J Respir Crit Care Med. 2010; 182(5): 693-718, doi: 10.1164/rccm.200811-1757ST, indexed in Pubmed: 20802169.

32. Salvi SS, Barnes PJ. Chronic obstructive pulmonary disease in non-smokers. Lancet. 2009; 374(9691): 733-743, doi: 10.1016/S0140-6736(09)61303-9, indexed in Pubmed: 19716966.

33. Gershon AS, Warner L, Cascagnette P, et al. Lifetime risk of developing chronic obstructive pulmonary disease: a longitudinal population study. Lancet. 2011; 378(9795): 991-996, doi: 10.1016/ S0140-6736(11)60990-2, indexed in Pubmed: 21907862.

34. American Thoracic Society Statement: Occupational contribution to the burden of airway disease. Am J Respir Crit Med. 2003; 167: 782-792.

35. Blanc PD, Iribarren C, Trupin L, et al. Occupational exposures and the risk of COPD: dusty trades revisited. Thorax. 2009; 64(1): 6-12, doi: 10.1136/thx.2008.099390, indexed in Pubmed: 18678700. 